\title{
REVIEW
}

\section{Effectiveness of area-based management in reducing bycatch of the New Zealand dolphin}

\author{
Elisabeth Slooten* \\ Department of Zoology, University of Otago, PO Box 56, Dunedin, New Zealand
}

\begin{abstract}
The New Zealand (NZ) dolphin Cephalorhynchus hectori, also known as Hector's dolphin, is endemic and listed as Endangered by the NZ Department of Conservation and the International Union for the Conservation of Nature. The North Island population, also known as Maui's dolphin, is listed separately as Critically Endangered. The Threat Management Plan for NZ dolphins identifies bycatch in gillnet and trawl fisheries as the number one threat. Fisheries mortality has resulted in rapid population declines, with current total population size estimated at $27 \%$ of 1970 numbers. Reduced use of gillnets and trawling in NZ dolphin habitat has slowed population declines in some areas. A long-term study in the Banks Peninsula Marine Mammal Sanctuary (South Island east coast) shows a significant increase in survival rates (by 5.4\%) and indicates that the previously rapid population decline has slowed substantially. Nationwide, NZ dolphin populations are predicted to continue declining under current management. This is driven mainly by continuing bycatch in areas with few or no dolphin protection measures (e.g. South Island north and west coasts). Extending protection to the $100 \mathrm{~m}$ depth contour throughout NZ dolphin habitat would result in rapid population recovery. This case study shows that areabased management can work, if the protected area is large enough, in the right place, effectively manages key threats, impacts are removed rather than displaced to other areas and no new threats are added (e.g. marine mining, tidal energy generation or pollution).
\end{abstract}

KEY WORDS: Marine Mammal Protected Areas · Area-based management · Bycatch · Bycatch solutions $\cdot$ Fisheries mortality $\cdot$ Hector's dolphin

\section{INTRODUCTION}

The New Zealand (NZ) dolphin Cephalorhynchus hectori, also known as Hector's dolphin, is endemic to NZ waters. The South Island population has been estimated at 7270 individuals (coefficient of variation $[\mathrm{CV}]=0.16$; Slooten et al. 2004). A line-transect survey of the North Island population, also known as Maui's dolphin $C$. hectori maui, resulted in an estimate of 111 individuals $(\mathrm{CV}=0.44$; Slooten et al. 2006). This population has recently been estimated at fewer than 80 individuals (Baker et al. 2012) and possibly as low as 55 individuals (Hamner et al. 2012).
These latest estimates are based on a genetic markrecapture study, which involved taking biopsy samples of individuals half adult size and larger, and therefore represent the number of individuals in the population that are larger than half adult size rather than total population size. NZ has 2 endemic marine mammal species, the NZ dolphin and the NZ sea lion (also known as Hooker's sea lion Phocarctos hookeri). Bycatch in fisheries is the most serious threat to both species, and can be avoided through the use of selective, sustainable fishing methods.

Since at least the early 1970s, NZ dolphins have been caught in commercial gillnet fisheries (Taylor 
1992, Baird \& Bradford 2000). Bycatch in trawl fisheries and amateur gillnets may extend back as far as the early 1900s, but has not been included in any of the risk analyses as no quantitative estimates are available (Baird \& Bradford 2000, Starr \& Langley 2000, DOC \& MFish 2007, Davies et al. 2008, Slooten \& Dawson 2010).

This paper provides a brief summary of research on the effectiveness of protection for NZ dolphins (e.g. Davies et al. 2008, Slooten \& Dawson 2010, Slooten \& Davies 2012), as a case study of the effectiveness of area-based management. The following abbreviations are used for different regions where NZ dolphins are found: WCNI (West Coast North Island), WCSI (West Coast South Island), ECSI (East Coast South Island), NCSI (North Coast South Island) and SCSI (South Coast South Island).

\section{HISTORY OF BYCATCH MANAGEMENT}

NZ dolphin densities have declined throughout the geographic range of the species since the 1970s, and the population has become more fragmented (DOC \& Mfish 2007, Davies et al. 2008, Slooten \& Dawson 2010, MPI \& DOC 2012). A major expansion of the NZ gillnet fishery started in the late 1960s, after the introduction of monofilament gillnets.

Until the late 1980s, gillnet and trawl fisheries operated throughout the range of NZ dolphins (Fig. 1A). Two independent risk analyses (Davies et al. 2008, Slooten \& Dawson 2010) concluded that populations of NZ dolphins were declining rapidly at this time. One of these studies was carried out by the National Institute of Water and Atmosphere, in collaboration with fishing industry researchers (Davies et al. 2008). The other was carried out by Otago University, in collaboration with scientists at the US National Marine Fisheries Service (Martien et al. 1999, Slooten et al. 2000, Slooten \& Dawson 2010).

The first protected area for NZ dolphins, the Banks Peninsula Marine Mammal Sanctuary, was created in 1988 by the Minister of Conservation, Helen Clark (Fig. 1B). New fishing regulations prohibited the use of gillnets inside most of the sanctuary. Exemptions were made for recreational gillnetting, which still continues inside harbours in winter, and trawling. Decisions on the offshore boundary of the protected area (4 nautical miles [n miles]), as well as northern and southern boundaries, involved compromises in order to reduce impact on the fishing industry. In 1988, Banks Peninsula was the only area with dolphin protection measures. These new regulations slowed the decline in the Banks Peninsula area. Nationwide, rapid population declines continued.

A second protected area was created by Minister of Fisheries, Pete Hodgson, in 2003 (Fig. 1C). New fishing regulations prohibited the use of gillnets inside most of the protected area. Exemptions included continuation of commercial and recreational gillnetting inside North Island harbours and in the southern part of the range of Maui's dolphin. Trawling was prohibited to $4 \mathrm{n}$ miles offshore in the central part of the range of Maui's dolphin, and to $2 \mathrm{n}$ miles offshore in other areas. Gillnets were prohibited to $4 \mathrm{n}$ miles offshore. In 2003, there was still no protection in other parts of NZ waters. Population declines were slowed, but not halted, in the 2 protected areas. Nationwide, rapid population declines continued.

In 2007, the Ministry of Fisheries (Mfish) and Department of Conservation (DOC) released a Threat Management Plan (DOC \& Mfish 2007), after several years of consultation with the fishing industry and other stakeholders. The Threat Management Plan concluded that fisheries mortality was still the most serious threat to the species, with bycatch in gillnets the number one threat and bycatch in trawl fisheries the second most serious threat.

In 2008, a more extensive package of protected areas was implemented by Minister of Fisheries, Jim Anderton, providing some protection in most of the areas where NZ dolphins are found (Fig. 1D). The offshore boundary of the North Island protected area was extended to $7 \mathrm{n}$ miles offshore, and protection was extended further into the entrance of the Manukau Harbour. Exemptions included a lack of protection along the southern North Island and NCSI. WCSI protection was extended to $2 \mathrm{n}$ miles offshore (a third of the dolphins' offshore range there of $6 \mathrm{n}$ miles) for 3 months of the year. Trawling was banned in some areas (e.g. to $2 \mathrm{n}$ miles offshore off ECSI and parts of WCNI), but continues throughout most of the range of NZ dolphin (e.g. WCSI, NCSI). Additional exemptions to the dolphin protection measures were implemented, to allow commercial and recreational fishers back into inshore fishing areas in Marlborough (northern region of ECSI) by Minister of Fisheries Phil Heatley (in 2011) and Minister for Primary Industries David Carter (in 2012). Overall, population declines were slowed or halted off WCNI and ECSI, with potential population recovery on SCSI. Population declines continued off WCSI and NCSI. Nationwide, population decline continued. 


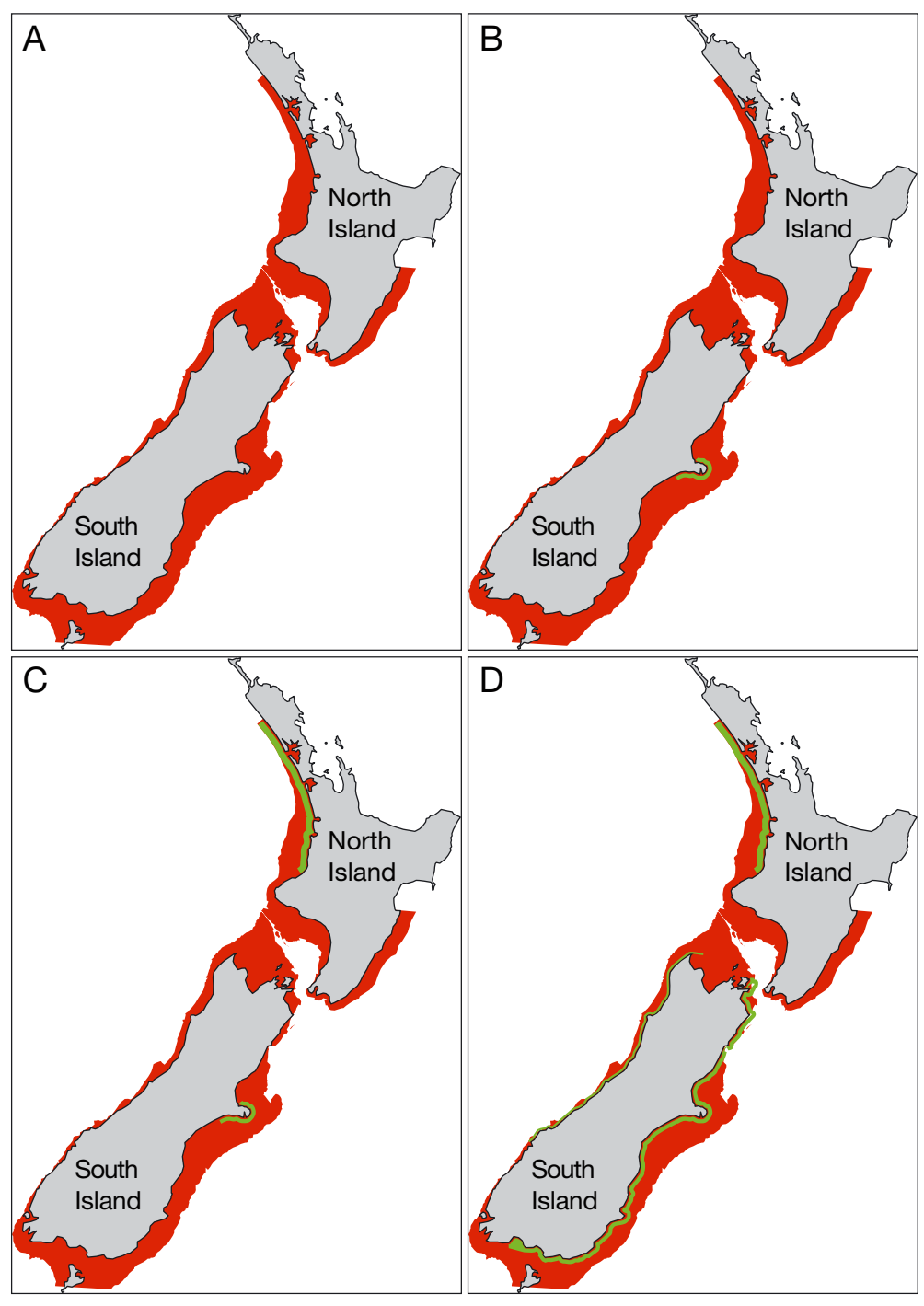

Fig. 1. History of protection measures, with New Zealand (NZ) dolphin Cephalorhynchus hectori habitat indicated in red, and protected areas in green. (A) 1970: gillnet and trawl fisheries operated throughout the range of NZ dolphins. NZ dolphin populations were declining rapidly. (B) 1988: first protected area was created — the Banks Peninsula Marine Mammal Sanctuary - slowing population decline in this area. Nationwide, rapid population declines continued. (C) 2003: second protected area created off the North Island west coast. Population declines slowed in the 2 protected areas. Nationwide, rapid population declines continued. (D) 2008: further dolphin protection measures implemented, providing some protection in most areas where NZ dolphins are found. Population declines slowed or halted in areas with relatively high level of protection. Nationwide, population decline continues

\section{FURTHER PROTECTION MEASURES}

In response to continuing dolphin deaths, the NZ government has extended the protection measures off WCNI. On 2 January 2012, a NZ dolphin was caught in a commercial gillnet off Cape Egmont, well south of the protected area on the WCNI. In July 2012, after public consultation, the Minister of Primary Industries David Carter put in place interim protection measures (Fig. 2A, Option 1). These extended the protected area to about $80 \mathrm{~km}$ south of where the dolphin death occurred on 2 January (the average NZ dolphin home range extends approximately $80 \mathrm{~km}$ alongshore). Following a second round of public consultation (MPI \& DOC 2012), the Minister will implement permanent protection measures (e.g. making the current extension permanent or further extending the protection measures).

The southern extension of the North Island protected area provides protection from gillnet fisheries only, and to $2 \mathrm{n}$ miles offshore rather than the $7 \mathrm{n}$ mile offshore boundary used in the rest of the WCNI protected area (see Fig. 2A). In addition, trawling continues in most of the protected area. So far, no protection has been provided for the area between the North and South Islands (e.g. NCSI). This continues to threaten the North Island population (Maui's dolphin). Population declines have been slowed or halted off the WCNI and ECSI. There is potential for population recovery on SCSI. Population declines continue off WCSI and NCSI. Nationwide population decline continues, with no significant difference in the projected outcome compared to the 2008 protection measures.

An expert panel, consisting of scientists from New Zealand and the USA, has been convened by the DOC and Ministry for Primary Industries. At a technical workshop in June 2012, the expert panel concluded that the range of Maui's dolphins extends further alongshore to at least Whanganui (Currey et al. 2012). This is a further $70 \mathrm{~km}$ or so beyond the boundary of the interim protection measures (extending to Hawera). The workshop also reviewed data on the continued overlap between Maui's dolphins and fishing methods known to cause dolphin mortality (gillnet and trawl fisheries), as well as results from risk analyses (including Davies et al. 2008, Slooten \& Dawson 2010, Slooten \& Davies 2012). The expert panel estimated the current bycatch of Maui's dolphins at 5 individuals $\mathrm{yr}^{-1}$, which is about 75 times higher than the 
potential biological removal (PBR) of 1 individual every 10 to $24 \mathrm{yr}$ (Currey et al. 2012). The PBR represents a sustainable level of total human impact that would allow a depleted population to recover to at least half of its original population size (Wade 1998, Slooten \& Dawson 2008). The expert panel estimated that fisheries mortality is responsible for $95.5 \%$, and all other threats combined for $4.5 \%$ of human-caused mortalities (including marine mining, pollution and tidal energy generation; Currey et al. 2012).

Bycatch in gillnet and trawl fisheries also continues in other parts of the range of NZ dolphins. For example on 22 February 2012, 2 dead NZ dolphins, entangled in a gillnet, were stranded on a beach north of Christchurch (ECSI). It is not clear whether this gillnet had been legally set beyond the $4 \mathrm{n}$ mile offshore boundary of the protected area, or illegally set within the protected area, nor whether it belonged to a commercial or 'recreational' fisher. Other dolphin mortalities since 2008 include NZ dolphins caught by fishing vessels carrying independent observers on the ECSI and found dead with gillnet cuts on the WCSI. Formal and informal reports from the fishing industry include NZ dolphin deaths on the SCSI and WCNI.

The Scientific Committee of the International Whaling Commission reviewed recent research on NZ dolphins and concluded that weak protection on

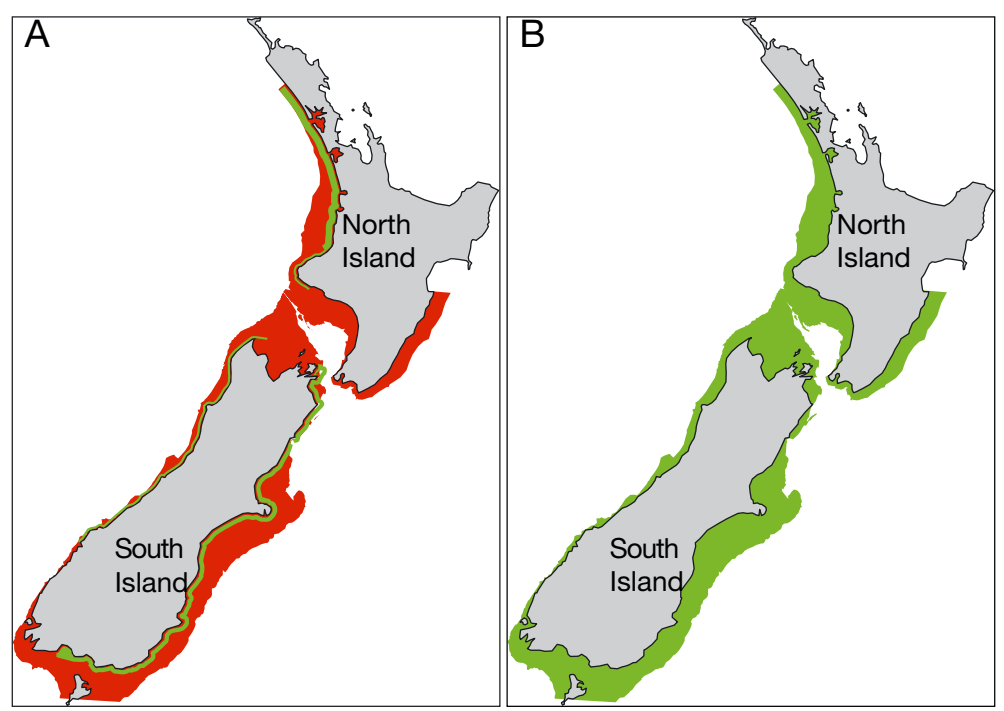

Fig. 2. Proposed extensions to protection for NZ dolphin, with NZ dolphin habitat indicated in red and protected areas in green. (A) 2013 - Option 1: interim protection measures extend the protected area along the southern West Coast North Island area (to 2 nautical miles offshore). No significant improvement in projected outcome. Nationwide, population decline continues. (B) 2013-Option 2: dolphin protection throughout NZ dolphin range in waters $<100 \mathrm{~m}$ deep, including harbours; NZ dolphins are rarely seen in waters deeper than $100 \mathrm{~m}$. Population recovery to around 15000 individuals within $40 \mathrm{yr}$
WCSI, a lack of protection on NCSI and 'exemption' areas in other regions are preventing species recovery (IWC 2012). The Scientific Committee expressed particular concern about the low abundance of Maui's dolphin and the rate of population decline. The Scientific Committee recommended protection from gillnet and trawl fisheries in waters $<100 \mathrm{~m}$ deep, including harbours, and stressed the importance of avoiding further population fragmentation by ensuring a safe 'conservation corridor' in Cook Strait, between North and South Islands (IWC 2012).

Likewise, the IUCN has recommended protection for NZ dolphins throughout their range, by banning gillnet and trawl fisheries in waters up to $100 \mathrm{~m}$ deep, including harbours (IUCN 2012). The IUCN recommendation (Fig. 2B, Option 2) would remove most of the compromises and exemptions to the current fishing regulations, providing effective protection for NZ dolphins throughout their range. There would still be a low level of fisheries mortality, from gillnet and trawl fisheries operating in areas where NZ dolphins are only rarely seen. Most NZ dolphins are found inside the $100 \mathrm{~m}$ depth contour (e.g. Dawson et al. 2004, Slooten et al. 2004, 2006), but sightings in deeper waters have been made off Kaikoura, Cloudy Bay and Clifford Bay (e.g. du Fresne \& Mattlin 2009). In addition, illegal fishing and occasional bycatch in craypot ropes and other fishing gear would still cause a low level of fisheries mortality. Lower-level human impacts, including pollution, marine mining, boat strikes and tidal energy generation, would also be responsible for a certain degree of mortality.

If populations recover in the future, protection for currently low-density areas (e.g. northeastern part of the North Island) may need to be reconsidered. Perhaps most importantly, Option 2 provides the 'corridors' urgently needed to reconnect North and South Island populations (Hamner et al. 2012).

\section{EFFECTIVENESS OF PROTECTION MEASURES}

\section{Population trends}

Several independent analyses have produced consistent results, despite large differences in model structure and parameterisation (for a review, see Slooten \& Davies 2012). It is clear that NZ dolphin 
populations have declined substantially due to dolphin mortality in commercial gillnet fisheries, and population recovery is unlikely under the current protection measures (Davies et al. 2008, Slooten \& Dawson 2010, Slooten \& Davies 2012). This is largely due to weak protection measures on the WCSI and a lack of protection in other areas (e.g. NCSI; see Fig. 2A).

Without fisheries mortality, NZ dolphin populations could almost double by 2050 to 15411 (CV $=0.16$; Slooten \& Dawson 2010) or 14650 (range 12313 to 19250; Davies et al. 2008), reaching half of the 1970 population size in $39 \mathrm{yr}(\mathrm{CV}=0.34$, Scenario $\mathrm{C}$ in Table 1, Fig. 3). By contrast, under current management, the probability of population recovery for the species as a whole is $20 \%$ if gillnets are removed from protected areas without being displaced to other areas of NZ dolphin habitat (Scenario B1 in Table 1, Fig. 3). The probability of recovery drops to $8 \%$ if half of the fishing effort is displaced to unprotected areas of dolphin habitat (Scenario B2). When population recovery was estimated to occur, it took $>1000 \mathrm{yr}$ for the total population to reach half of the 1970 population size (Table 1).

Guidelines for implementing the US Marine Mammal Protection Act state that fishery mortality should not delay recovery of endangered species by $>10 \%$ (Barlow et al. 1995). In the case of NZ dolphins, this would require recovery to half the 1970 population size within $43 \mathrm{yr}(39 \mathrm{yr}+10 \%)$. Under current management, population decline is the most likely outcome $(80 \%$ of runs for Scenario B1, $92 \%$ for B2, $100 \%$ for B3). In the unlikely event of population recovery $(20 \%$ of runs for Scenario B1, $8 \%$ for $\mathrm{B} 2$, no recovery for B3), it would take $>1000$ yr to recover to half of the 1970 population size. Recovery was also delayed by $>10 \%$ for each of the regional populations. Under Scenario B1, for example, recovery to half of the 1970 population size was estimated to take more than 19, 217, 306 and 1000 $\mathrm{yr}$, respectively, for the regional populations, and exceeded the time to recovery for Scenario $\mathrm{C}$ by much more than $10 \%$.

\section{Data from independent observers on fishing vessels}

The NZ National Institute of Water and Atmosphere estimated that dur-

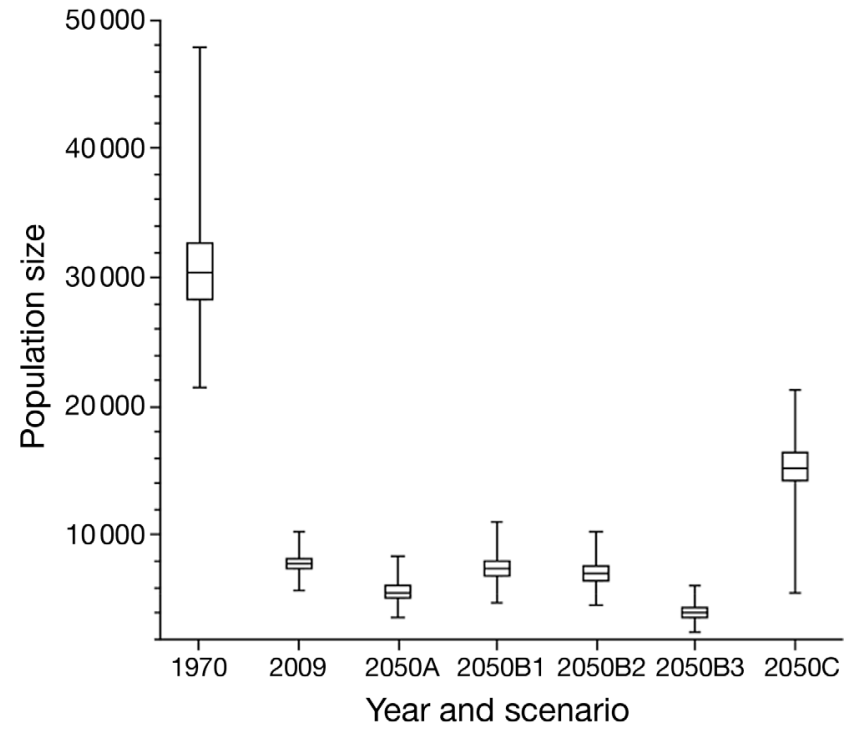

Fig. 3. Estimated total population size for NZ dolphin in 1970, 2009 and 2050. Population size estimates for 2050 are shown for 5 management scenarios: (A) Past management; (B) current protection measures with (B1) all fishing effort from protected areas has been removed from the fishery, (B2) half of the fishing effort from protected areas has been displaced to unprotected areas, (B3) all fishing effort has been displaced and dolphin mortality in trawl and recreational gillnet fisheries is included in the analysis; and (C) no fisheries mortality. Boxes indicate upper and lower quartiles (25th and 75th percentile), the line inside each box is the median (50th percentile), and the whiskers indicate the range of the 5000 population size estimates resulting from each simulation (for more information, see Slooten \& Dawson 2010)

Table 1. Cephalorhynchus hectori. Recovery to half of the population size in 1970. Estimates presented for each regional area and scenario-recovery: proportion of 5000 model runs in which the population recovers; $<1000$ yr: proportion of runs in which the population recovered in $<1000 \mathrm{yr}$; average: average number of years to recovery (coefficient of variation in parentheses), only for those runs where recovery took $<1000$ yr (from Slooten \& Dawson 2010). For a description of scenarios see Fig. 3. na: not applicable (zero probability of recovery)

\begin{tabular}{|c|c|c|c|c|c|c|}
\hline \multirow{2}{*}{\multicolumn{2}{|c|}{ Scenario }} & \multirow[t]{2}{*}{ North Island } & \multicolumn{3}{|c|}{ South Island } & \multirow{2}{*}{$\begin{array}{c}\text { Total } \\
\text { population }\end{array}$} \\
\hline & & & East & West & South & \\
\hline \multirow[t]{3}{*}{ A } & Recovery & 0.88 & 0.00 & 0.00 & 0.03 & 0.00 \\
\hline & $<1000 \mathrm{yr}$ & 0.00 & na & na & 0.00 & na \\
\hline & Average & na & na & na & na & na \\
\hline \multirow[t]{3}{*}{ B1 } & Recovery & 1.00 & 0.71 & 0.01 & 1.00 & 0.20 \\
\hline & $<1000 \mathrm{yr}$ & 0.03 & 0.03 & 0.00 & 1.00 & 0.00 \\
\hline & Average & $217(0.75)$ & $306(0.86)$ & na & $19(2.96)$ & na \\
\hline \multirow[t]{3}{*}{ B2 } & Recovery & 0.00 & 0.71 & 0.01 & 1.00 & 0.08 \\
\hline & $<1000 \mathrm{yr}$ & na & 0.00 & 0.00 & 0.34 & 0.00 \\
\hline & Average & na & na & na & $24(4.90)$ & na \\
\hline \multirow[t]{3}{*}{ B3 } & Recovery & 0.00 & 0.00 & 0.00 & 0.09 & 0.00 \\
\hline & $<1000 \mathrm{yr}$ & na & na & na & 0.01 & na \\
\hline & Average & na & na & na & $207(1.52)$ & na \\
\hline \multirow[t]{3}{*}{ C } & Recovery & 1.00 & 1.00 & 1.00 & 1.00 & 1.00 \\
\hline & $<1000 \mathrm{yr}$ & 0.96 & 1.00 & 0.94 & 1.00 & 1.00 \\
\hline & Average & $88(0.71)$ & $25(0.44)$ & $72(0.88)$ & $4(5.04)$ & $39(0.34)$ \\
\hline
\end{tabular}


ing the period from 2000 to 2006 an estimated 110 to $150 \mathrm{NZ}$ dolphins were killed in gillnet fisheries each year (Davies et al. 2008). Of these, 35 to $46 \mathrm{yr}^{-1}$ were caught off the ECSI, and the dolphin protection measures implemented in 2008 have reduced this to $23 \mathrm{yr}^{-1}(\mathrm{CV}=0.21$; Slooten \& Davies 2012). This indicates that the effectiveness of the current protection measures off ECSI is intermediate between Scenarios B2 and B3 (Table 1, Fig. 3). The relatively high level of ongoing dolphin bycatch and sightings made by fisheries observers outside the current protected areas (e.g. Figs. 4 to 6), indicate that there is still considerable overlap between NZ dolphins and gillnet and trawl fisheries (Mfish 2012).

\section{Strandings and reported bycatch}

Scientifically robust data on dolphin bycatch, before and after 2008, are available only for ECSI. In all other areas, the observer coverage has been too low to provide estimates of the number of dolphins caught per year. In the absence of catch rates from an

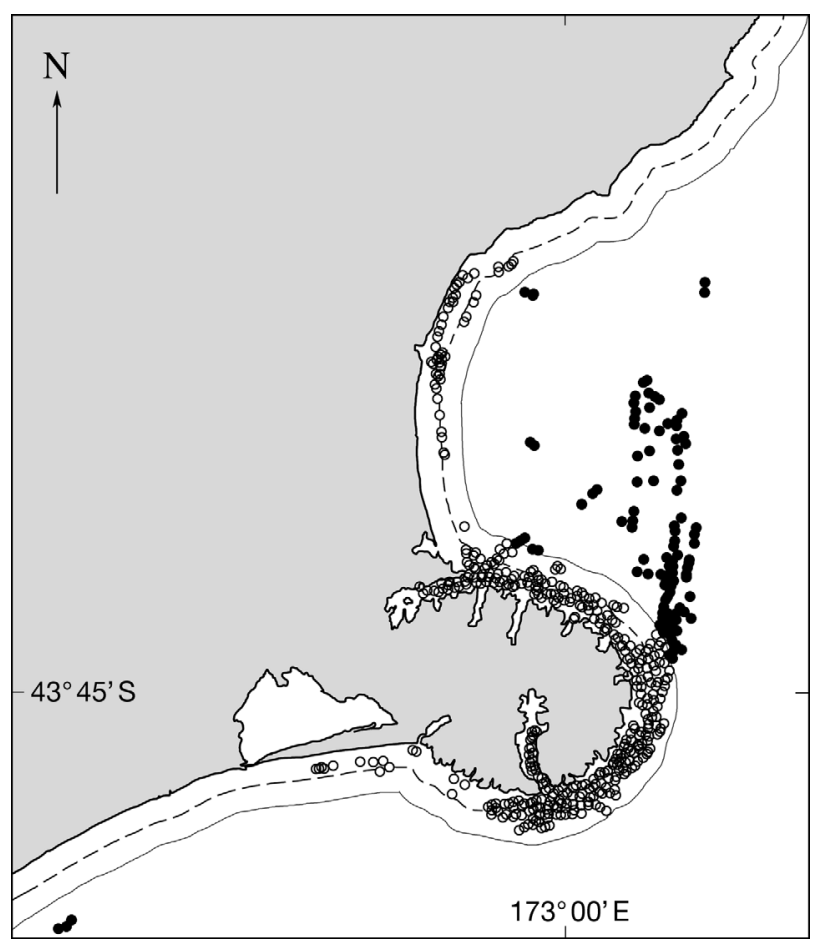

Fig. 4. NZ dolphin sightings made by independent observers on commercial fishing vessels around Banks Peninsula (East Coast South Island). O: dolphin sightings inside protected areas; •: dolphin sightings in areas where both gillnets and trawling gear are used; solid offshore line: area where gillnets are prohibited; dashed line: area where trawling is prohibited

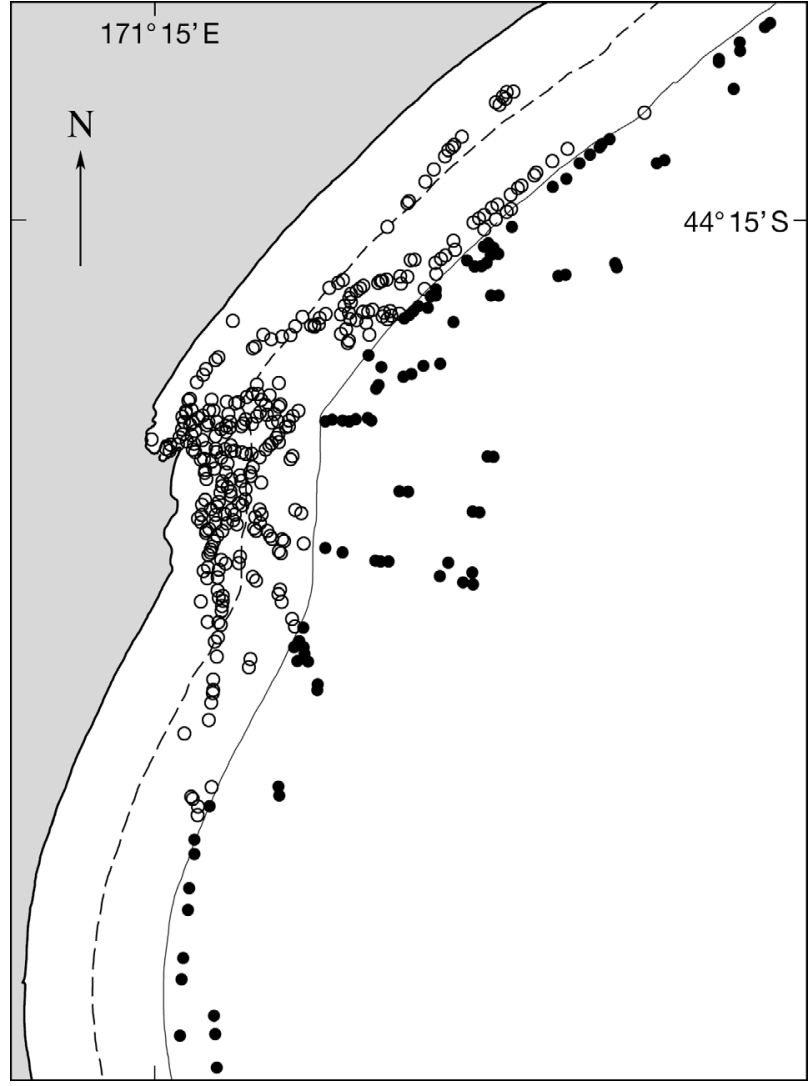

Fig. 5. NZ dolphin sightings made by independent observers on commercial fishing vessels south of Banks Peninsula (East Coast South Island). o: dolphin sightings inside protected areas; •: dolphin sightings in areas where both gillnets and trawling gear are used; solid offshore line: area where gillnets are prohibited; dashed line: area where trawling is prohibited

adequate observer programme, the DOC's database of strandings and bycatch reported by fishers and fisheries observers (DOC 2012) provides information for making a qualitative comparison of the number of dolphin deaths before and after the current protection measures were implemented in 2008.

The data in the DOC database do not result from systematic surveys (e.g. weekly beach surveys or data from observers on fishing vessels). In most cases, a dead dolphin was found by a member of the public and reported to DOC or Mfish. Therefore, these numbers are not an indication of the total number of dolphin deaths in the population, nor the total number caught in fishing nets. They are, at best, a qualitative indication of dolphin mortality. For example, regions differ in currents, water depth, slope of beach, fishery (including how close to shore vessels are operating), affecting the probability of a dead dolphin stranding in the first place. In addition, there 


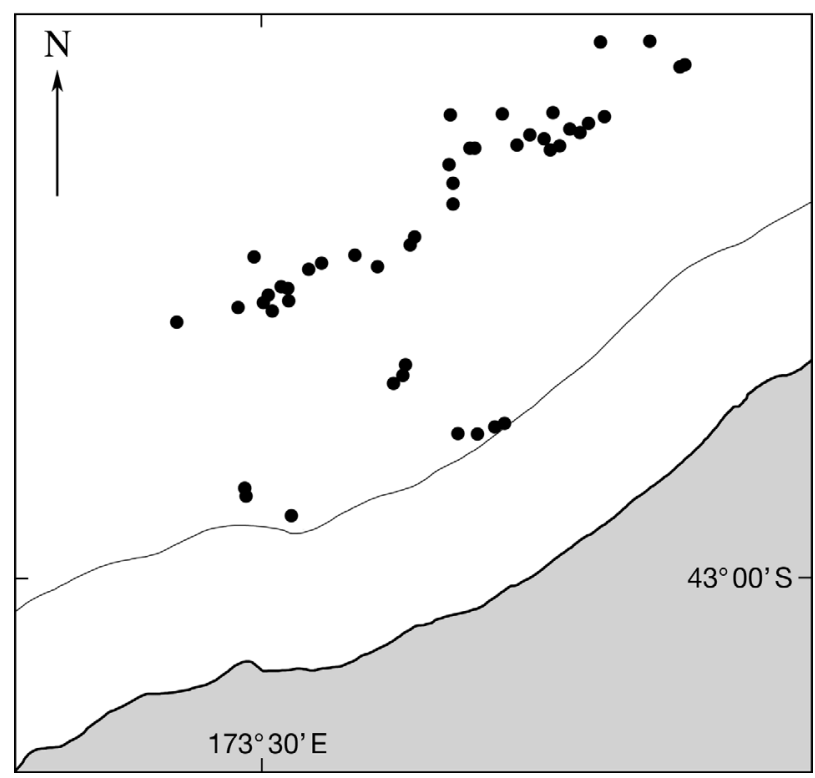

Fig. 6. NZ dolphin sightings made by independent observers on commercial fishing vessels off West Coast South Island. Dolphin sightings $(\bullet)$ were made only outside the protected area (indicated by thin, offshore line). Gillnetting is prohibited inside the protected area from 1 December to 28 February. The WCSI does not have any trawling restrictions

are regional differences in the number of people visiting beaches, DOC capacity to find and retrieve the animal, etc.

Bearing these limitations in mind, the average number of dead dolphins per year is compared between the periods from 1970 to 2008 and 2009 to 2012 for each region. The 'before' period starts in 1970 for several reasons. The NZ gillnet fishery expanded dramatically in the late 1960s and early 1970 s, records are very sparse before 1970 for all regions and 1970 is the year used for estimating population sizes of 'original' pre-fisheries bycatch in the risk analyses described above. The new protection measures were implemented in late 2008. Therefore, a comparison is made between the average number of dolphin deaths per year, before and after 2008.

In the far north and far south, bycatch increased slightly over time. For the WCNI, there was 1.00 dolphin death $\mathrm{yr}^{-1}$ from 1970 to 2008 and 1.33 dolphin deaths $\mathrm{yr}^{-1}$ from 2009 to 2012 . The protected area off the WCNI was originally put in place in 2003. Therefore, it is also useful to compare the periods before and after 2003. Again, an average of 1.00 dolphin death $\mathrm{yr}^{-1}$ from 1970 to 2002, increases slightly to $1.11 \mathrm{yr}^{-1}$ from 2003 to 2012 . On the SCSI, the number of dolphin deaths changed from 0.64 between 1970 and 2002 to $0.67 \mathrm{yr}^{-1}$ between 2003 and 2012. Off the
WCSI, the number of dolphin deaths decreased slightly from $3.79 \mathrm{yr}^{-1}$ from 1970 to 2008 to $3.33 \mathrm{yr}^{-1}$ on average from 2009 to 2012. In summary, there is no indication - from the number of dead dolphins in the DOC database - of a substantial reduction in dolphin bycatch for the WCNI, WCSI, NCSI, or SCSI as a result of the 2008 protection measures.

\section{Protected area design with respect to dolphin distribution}

In most areas, the distribution of NZ dolphins extends well beyond the offshore boundary of the protected area. For example, at Banks Peninsula 3 yr of aerial surveys show that while trawling is banned to $2 \mathrm{n}$ miles and gillnetting to $4 \mathrm{n}$ miles offshore, the distribution of NZ dolphins extends to at least $20 \mathrm{n}$ miles offshore (Rayment et al. 2010). In addition, there are exemptions for trawlers with a headline height $<1 \mathrm{~m}$ (these are allowed to fish throughout the area) and recreational gillnetting (which continues between 1 April and 1 October in designated harbours). The proportion of the dolphin population found inside the protected area varies seasonally. NZ dolphin sightings were concentrated close to shore in shallow water in summer, but were more evenly distributed with respect to distance from shore and water depth during winter. A higher proportion of the dolphin sightings was made outside the protected area in winter $($ mean $=56 \%)$ than in summer $($ mean $=19 \%$, $G=88.25, \mathrm{df}=1, \mathrm{p}<0.001$; Fig. 7).

Likewise, off the WCSI, protection from gillnets extends to $2 \mathrm{n}$ miles offshore (for 3 months of the year), while NZ dolphins range to $6 \mathrm{n}$ miles offshore in this area (Rayment et al. 2011). There are no trawling regulations on the WCSI. Again, in Cloudy Bay and Clifford Bay (ECSI), protection measures extend to $4 \mathrm{n}$ miles offshore, while the NZ dolphin distribution extends to at least $15 \mathrm{n}$ miles offshore (du Fresne \& Mattlin 2009). In most areas, NZ dolphins are found in waters up to $100 \mathrm{~m}$ deep (Dawson et al. 2004, Slooten et al. 2004, 2006). The offshore distance of the $100 \mathrm{~m}$ depth contour varies around the country (see red area in Figs. 1 \& 2).

\section{Evidence from survival rates}

Survival rates of NZ dolphins in the Banks Peninsula area have increased by $5.4 \%$ since the creation of the Banks Peninsula Marine Mammal Sanctuary (Fig. 8; Gormley et al. 2012). The population was 


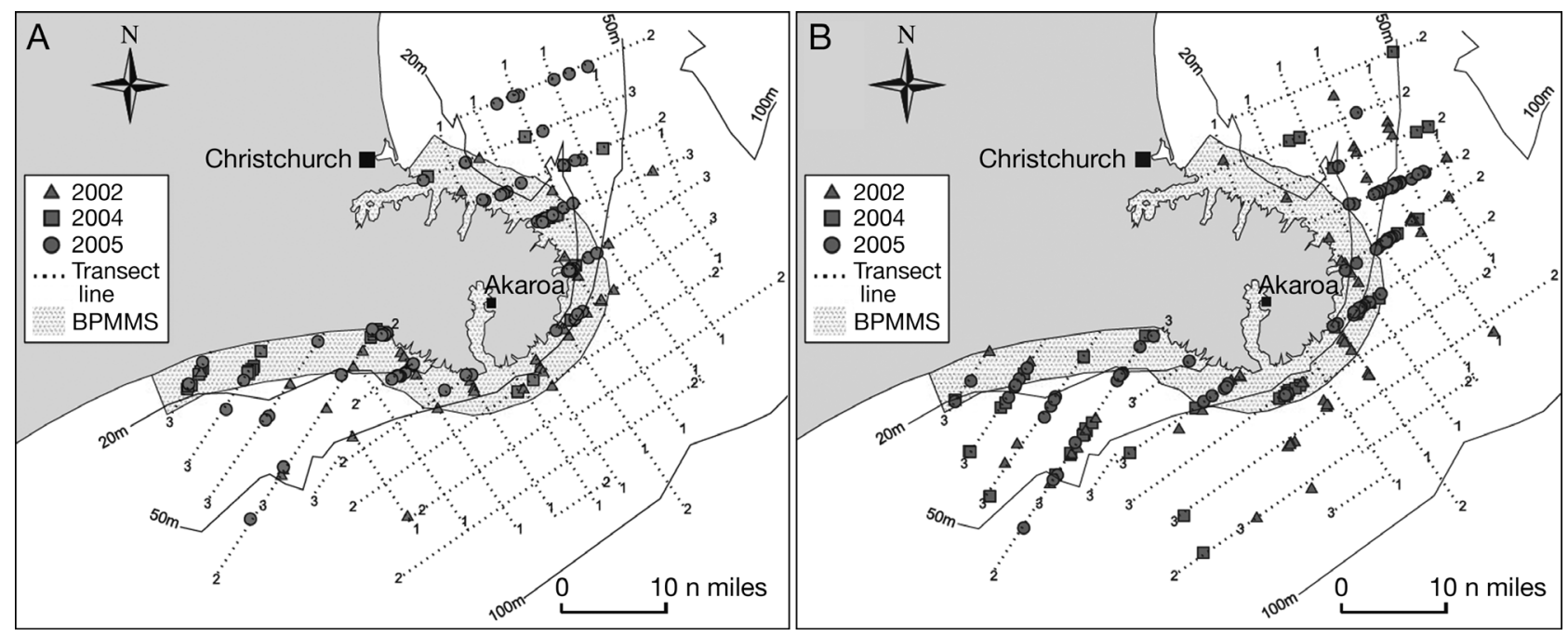

Fig. 7. Offshore distribution of NZ dolphins around Banks Peninsula in (A) summer and (B) winter, with respect to the offshore boundary of the Banks Peninsula Marine Mammal Sanctuary (BPMMS) at the time of the survey. The numbers at the end of the transect lines indicate the number of years each line was surveyed

declining rapidly before the Sanctuary was created, and is now declining slowly (Slooten \& Dawson 2010). Clearly, marine mammal protected areas can result in measurable improvements. However, the Banks Peninsula Marine Mammal Sanctuary is still too small and the regulations too weak to result in a stable, let alone recovering population (Rayment et al. 2010, Gormley et al. 2012). NZ dolphins around Banks Peninsula range to $20 \mathrm{n}$ miles offshore (Rayment et al. 2010). Gillnets are banned to a distance of $4 \mathrm{n}$ miles offshore, and trawling, up to $2 \mathrm{n}$ miles offshore. No quantitative estimates of trawl bycatch are available, due to low levels of observer coverage. However, the observer data suggest that the total number of dolphins caught in trawl nets could be as

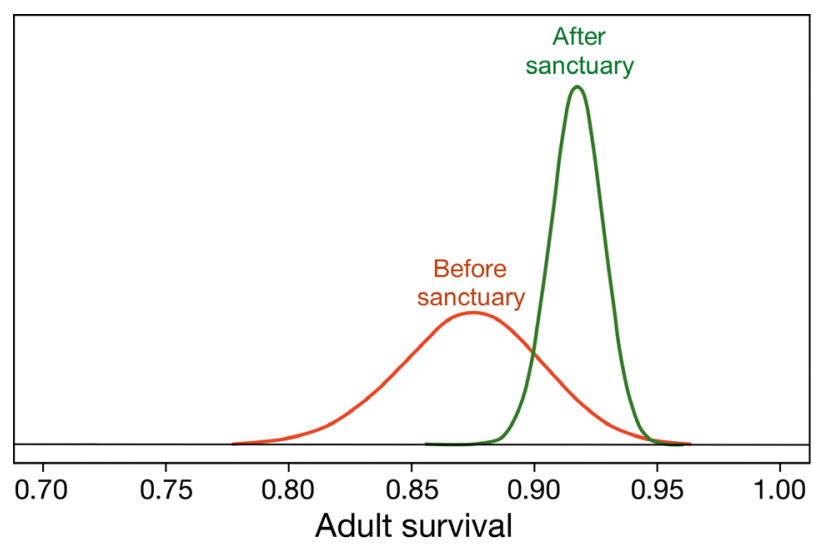

Fig. 8. Posterior distributions for survival rates of NZ dolphins in the Banks Peninsula area, before and after the creation of the Banks Peninsula Marine Mammal Sanctuary (from Gormley et al. 2012) high as the number caught in gillnets (Baird \& Bradford 2000). This may help explain why the survival rates, while much higher than in the past, are still too low to allow population recovery.

\section{CONCLUSIONS}

The history of conservation management for NZ dolphins follows a slow progression from 1 small protected area, created in 1988, to 2 protected areas by 2003, a more extensive network of protected areas created in 2008 and further extensions proposed for 2013. Each of these improvements in the protection measures has been preceded by a period of public consultation (usually 1 to 3 yr). Further extensions of the protection measures were being considered at the time this paper was accepted for publication. Two rounds of public consultation took place during 2012, and a final decision is expected in 2013.

The overarching goal has been to reduce the overlap between NZ dolphins and fishing methods known to cause dolphin mortality (in particular gillnets and trawling). Data on bycatch, dolphin survival and the rate of population decline indicate that this can be effective.

The NZ dolphin case study indicates that protected areas can work if

- They are the right size

- They are in the right place

- They effectively manage the threat(s)

- Threats are removed, rather than displaced to another area 
- Follow-up monitoring is used to determine effectiveness and modify boundaries or regulations if necessary

- No new impacts, such as marine mining, tidal energy generation or pollution, are added

In several areas, population surveys and data from observer programmes indicate that there is still considerable overlap between NZ dolphins and gillnet and trawl fisheries, resulting in unsustainable levels of bycatch. The history of managing fisheries bycatch for NZ dolphins shows that managing fisheries in specific, relatively small areas is likely to shift the problem - to another area that is still an important part of the species' range-rather than solve it. In general, small protected areas (e.g. confined to 'critical habitat') are unlikely to provide an effective solution to a widespread problem. Clearly, a serious problem that operates at a large scale (e.g. throughout a species' habitat) will require a large-scale solution. In this case, protection throughout the NZ dolphin's habitat, out to the $100 \mathrm{~m}$ depth contour, would substantially increase the potential for population recovery and would reduce population fragmentation.

Acknowledgements. I am very grateful to the many colleagues who contributed their time and crucial insights into the research reviewed in this paper, including Barbara Taylor and Karen Martien (US National Marine Fisheries Service), Stephanie Burkhart (US Coast Guard), Steve Dawson, David Fletcher, Will Rayment, Trudi Webster and Richard Barker (Otago University), Andrew Gormley (Landcare NZ) and Nick Davies (National Institute of Water and Atmosphere in NZ and Oceanic Fisheries Programme in New Caledonia). The work described in this paper has been discussed with representatives from government agencies, the fishing industry, recreational fishers and other stakeholders in meetings that formed part of the development of a 'Threat Management Plan' for NZ dolphin and other meetings organised by the NZ Department of Conservation and Ministry of Fisheries. An earlier version of this paper was presented at the International Marine Mammal-Gillnet Bycatch Mitigation Workshop (Woods Hole, October 2011). I thank the workshop participants for their constructive criticism and helpful suggestions. Many thanks to Karin Forney and other (anonymous) reviewers of this paper.

\section{LITERATURE CITED}

Baird SJ, Bradford E (2000) Estimation of Hector's dolphin bycatch from inshore fisheries, 1997-98 fishing year. Published Client Report on Contract 3024. Department of Conservation, Wellington. www.doc.govt.nz/documents/ science-and-technical/CSL3024.pdf (accessed 20 February 2013)

Baker CS, Hamner RM, Cooke J, Heimeier D, Vant M, Steel D, Constantine R (2012) Low abundance and probable decline of the critically endangered Maui's dolphin estimated by genotype capture-recapture. Anim Conserv, doi:10.1111/j.1469-1795.2012.00590.x

Barlow J, Swartz SL, Eagle TC, Wade PR (1995) US marine mammal stock assessments: guidelines for preparation, background, and a summary of the 1995 assessments. NOAA Tech Memo NMFS-OPR-6

Currey RJC, Boren LJ, Sharp BR, Peterson D (2012) A risk assessment of threats to Maui's dolphins. Ministry for Primary Industries and Department of Conservation, Wellington. www.doc.govt.nz/getting-involved/consultations/ closed/threat-management-plan-review-for-mauis-dolphin/ consultion-paper/ (accessed 10 January 2013)

Davies NM, Bian R, Starr P, Lallemand P, Gilbert D, McKenzie J (2008) Risk analysis for Hector's dolphin and Maui's dolphin subpopulations to commercial set net fishing using a temporal-spatial age-structured model. Ministry of Fisheries, Wellington. www.fish.govt.nz/NR/rdonlyres/ B034115D-247A-42E5-B08F-F5D267046C59/0/HectorNIW Ariskanalysis.pdf (accessed 14 March 2013)

Dawson SM, Slooten E, du Fresne S, Wade P, Clement D (2004) Small-boat surveys for coastal dolphins: line-transect surveys for Hector's dolphins (Cephalorhynchus hectori). Fish Bull 201:441-451

DOC (Department of Conservation) (2012) Database of strandings, observed bycatch and bycatch voluntarily reported by fishers. www.doc.govt.nz/conservation/nativeanimals/marine-mammals/dolphins/hectors-dolphin/docswork/hectors-dolphin-incident-database/ (accessed 10 January 2013)

DOC \& MFish (Department of Conservation and Ministry of Agriculture \& Fisheries) (2007) Hector's dolphin threat management discussion document, April 2007. www. fish.govt.nz/en-nz/Consultations/Archive/2008/Hectors +dolphins/Threat+Management+Plan.htm (accessed 14 March 2013)

du Fresne S, Mattlin R (2009) Distribution and abundance of Hector's dolphin (Cephalorhynchus hectori) in Clifford and Cloudy Bays. Available from the Marlborough District Council, Blenheim

Gormley AM, Slooten E, Dawson SM, Barker RJ, Rayment W, du Fresne S, Bräger S (2012) First evidence that marine protected areas can work for marine mammals. J Appl Ecol 49:474-480

Hamner RM, Oremus M, Stanley M, Brown P, Constantine R, Baker CS (2012) Estimating the abundance and effective population size of Maui's dolphins using microsatellite genotypes in 2010-11, with retrospective matching to 2001-07. Department of Conservation Report. www.doc. govt.nz/documents/conservation/native-animals/marinemammals/mauis-dolphin-abundance-estimate-report.pdf (accessed 28 February 2013)

IUCN (2012) Actions to avert the extinctions of rare dolphins: Maui's dolphins, Hector's dolphins, Vaquita and South Asian river dolphins. Motion 35, adopted at the IUCN World Conservation Congress, Jeju, 2012. http:// portals.iucn.org/2012motions/ (accessed 20 February 2012)

IWC (International Whaling Commission) (2012) Report of the scientific committee of the International Whaling Commission. http://iwc.int/scientifc-committee-reports (accessed 15 March 2013)

> Martien KK, Taylor BL, Slooten E, Dawson S (1999) A sensitivity analysis to guide research and management for Hector's dolphin. Biol Conserv 90:183-191 
Mfish (Ministry of Fisheries) (2012) Report on observer programme results. Ministry for Primary Industries, Wellington. www.fish.govt.nz/en-nz/Environmental/Summer+ Observer+Programme.htm? \&MSHiC $=65001 \& \mathrm{~L}=10 \& \mathrm{~W}=$ ministers_briefing_observer $\% 20 \&$ Pre $=\% 3 \mathrm{Cspan} \% 20$ class $\% 3 \mathrm{~d} \% 27$ SearchHighlight $\% 27 \% 3 \mathrm{E} \& \mathrm{Post}=\% 3 \mathrm{C} / \mathrm{span} \% 3 \mathrm{E}$ (accessed 15 March 2013)

MPI \& DOC (Ministry for Primary Industries and Department of Conservation) (2012) Review of the Maui's dolphin Threat Management Plan: consultation paper. MPI \& DOC, Joint discussion paper No: 2012/18. www.doc. govt.nz/mauisconsultation (accessed 15 March 2013)

Rayment W, Dawson SM, Slooten E (2010) Seasonal changes in distribution of Hector's dolphin at Banks Peninsula, New Zealand: implications for protected area design. Aquat Conserv 20:106-116

Rayment W, Clement D, Dawson S, Slooten E, Secchi E (2011) Distribution of Hector's dolphin (Cephalorhynchus hectori) off the west coast, South Island, New Zealand, with implications for the management of bycatch. Mar Mamm Sci 27:398-420

Slooten E, Davies N (2012) Hector's dolphin risk assessments: old and new analyses show consistent results. J R Soc N Z 42:49-60

Slooten E, Dawson SM (2008) Sustainable levels of human impact for Hector's dolphin. Open Conserv Biol J 2:37-43

Slooten E, Dawson SM (2010) Assessing the effectiveness of

Editorial responsibility: Tim Werner,

Boston, Massachusetts, USA conservation management decisions: likely effects of new protection measures for Hector's dolphin. Aquat Conserv Mar Freshw Ecosyst 20:334-347

> Slooten E, Fletcher D, Taylor BL (2000) Accounting for uncertainty in risk assessment: case study of Hector's dolphin mortality due to gillnet entanglement. Conserv Biol 14:1264-1270

Slooten E, Dawson SM, Rayment WJ (2004) Aerial surveys for coastal dolphins: abundance of Hector's dolphins off the west coast South Island, NZ. Mar Mamm Sci 20: $477-490$

> Slooten E, Dawson SM, Rayment WJ, Childerhouse SJ (2006) A new abundance estimate for Maui's dolphin: What does it mean for managing this critically endangered species? Biol Conserv 128:576-581

Starr P, Langley A (2000) Inshore fishery observer programme for Hector's dolphins in Pegasus Bay, Canterbury Bight, 1997/98. Published Client Report on Contract 3020. Department of Conservation, Wellington. www.doc. govt.nz/documents/science-and-technical/CSL3020.pdf (accessed 20 February 2013)

Taylor PR (1992) Incidental catch of non-fish species in setnets in NZ waters. NZ Fisheries Assessment Research Document 92/21. Ministry of Fisheries, Wellington

Wade PR (1998) Calculating thresholds to the humancaused mortality of cetaceans and pinnipeds. Mar Mamm Sci 14:1-37

Submitted: June 12, 2012; Accepted: October 31, 2012 Proofs received from author(s): March 14, 2013 